\title{
Population dynamics of mustard aphid Lipaphis erysimi Kalt. on different varieties of Indian mustard and their relationship with prevailing weather parameters
}

\author{
Awaneesh Chandra', Y.P. Malik² and Anoop Kumar*2 \\ ${ }^{1}$ Department of Entomology, C.S.A. University of Agriculture and Technology, Kanpur (U.P.) India \\ ${ }^{2}$ ICAR- National Research Centre for Integrated Pest Management, New Delhi (India)
}

\section{ARITCLE INFO}

Received : 16.08 .2019

Revised : 10.09 .2019

Accepted : 24.09 .2019

\section{KEY WORDS :}

Population dynamics, Lipaphiserysimi, Brassica juncea, Weather parameters
*Corresponding author:

Email : robincsa@gmail.com

\begin{abstract}
An experiment was conducted during Rabi 2008-2009 and 2009-2010. Aphid appeared in first week of January when the maximum temperature was $\left(15.8-16.1^{\circ} \mathrm{C}\right)$ and minimum temperature $\left(5.3-8.0^{\circ} \mathrm{C}\right)$ along with relative humidity 93.0-95.3 per cent maximum, 66.082.9 per cent minimum and wind speed $2.6 \mathrm{~km} / \mathrm{h}$ during 2008-09 and 2009-10, respectively. The peak intensity of aphids on different varieties of Indian mustard during $7^{\text {th }}$ standard week (Feb., 12-18) in respective years, when the temperature was $23.1-25.1^{\circ} \mathrm{C}$ maximum and $9.4-12.5^{\circ} \mathrm{C}$ minimum along with relative humidity maximum $89.0-91.0$ per cent and minimum 43.0-69.0 per cent during 2008-09 and 2009-10, respectively. The aphid population was completely wiped out from mustard crop in the last week of February and first week of March, when the crop age was 118 days. At this stage, temperature was $29.7-31.7^{\circ} \mathrm{C}$ maximum and $12.7-15.7^{\circ} \mathrm{C}$ minimum along with relative humidity maximum 73.0-78.0 per cent and minimum 34.0-36.0 per cent during 2008-09 and 2009-10, respectively. Simple correlation co-efficient of aphid with weather factors showed a positive relationship with temperature $(\mathrm{r}=0.226-0.645$ and $0.900-0.961)$ and wind speed $(\mathrm{r}=0.434-0.651$ and $0.599-0.684)$, while negative impact with relative humidity $(\mathrm{r}=-0.579$ to -0.765 and -0.526 to -0.633 ) during both the years.
\end{abstract}

How to view point the article : Chandra, Awaneesh, Malik, Y.P. and Kumar, Anoop (2019). Population dynamics of mustard aphid Lipaphis erysimi Kalt. on different varieties of Indian mustard and their relationship with prevailing weather parameters. Internat. J. Plant Protec., 12(2) : 160-165, DOI : 10.15740/HAS/IJPP/12.2/160-165, Copyright@ 2019: Hind AgriHorticultural Society. 